\title{
Systematizing Internationalization Policy of Higher Education in State Islamic Universities
}

\author{
Muhammad Munadi ${ }^{1}$ \\ ${ }^{1}$ IAIN SURAKARTA, Indonesia \\ Correspondence: Muhammad Munadi, IAIN SURAKARTA, Indonesia. \\ Received: August 2, 2020 \\ Accepted: August 28, 2020 \\ Online Published: August 31, 2020 \\ doi:10.5430/ijhe.v9n6p96 \\ URL: https://doi.org/10.5430/ijhe.v9n6p96
}

\begin{abstract}
The phenomenon of globalization affects all sectors including higher education in Indonesia. This research aimed to determine strategic planning, research activities, and curriculum of internationalization policy. The research used qualitative approach to analyze internationalisation in the State Islamic University of Yogyakarta and State Islamic University of Malang. The results showed that the strategic planning of internationalization is coordinated in all levels. The implementation of international curriculum is through foreign language and multicultural skills teachings. The development of international scientific journal cited internationally and the development of lecturers for scientific publications cited internationally cited. State islamic universities performed internationalization with competency perspective.
\end{abstract}

Keywords: competency, Islamic higher education, implementation, internationalization, policy

\section{Introduction}

Globalization is a current phenomenon that cannot be avoided by almost all countries including Indonesia. It impacts all sectors of life including higher education. Whitaker (2004) stated that globalization affects many sectors of society, and higher education is no exception. Universities worldwide respond to challenges presented by globalization in various ways, one of which is the internationalization of the university. According to Levin (1999) there are 12 aspects of globalization that affect collegiate institutions, namely:

1) Internationalization (students, curriculum, delivery)

2) Public sector funding constraints

3) Private sector interaction

4) Electronic technology, real-time communications

5) Productivity and efficiency

6) External competition

7) Restructuring

8) Labor alterations (e.g., additional work)

9) State intervention

10) Partnerships

11) Workforce training

12) Commodification

The statement indicates that there is a link between globalization and internationalization. Related to this, Albatch (2004) stated that internationalization is a consequence of globalization. Internationalization of education is often understood as a necessity of globalization in which every educational institution will seek to provide its competitive advantage. Internationalization of education is expected to open access to knowledge globally, enlarge opportunities to participate in international research, generate global recognition of outputs (graduates, papers, and research results). According to Jiang (2007), globalisation has facilitated and quickened the pace of the internationalisation of Higher Education. Knight (1997) further corroborates that "globalisation can be thought of as catalyst while internationalisation is the response, albeit a response in a proactive way". Cantwell and Maldonado-Maldonado 
(2009) support this opinion by stating that internatinalisation is understood as the ways in which institutions of higher education respond to globalisation. This opinion is further confirmed by Kushnarenko (2010) stating that it (internationalization) provides universities with educational models that can respond efficiently to current issues and challenges of globalization.

Internationalization and globalization are two terms that can be considered the same and are sometimes interchanged. The definition of globalization and internationalization, in a simple term, according to Djokopranoto and Indrajit (2004) is a global integration of all aspects of life without any territorial restrictions which made possible the occurrence of exchange, trade, dissemination of resources (capital, human, science, and technology).

The emphasis in globalization lies in the global integration of all countries through the process of free trade, the movement of capital, the migration of human resources, capital resources, science resources and technology resources without being controlled and prevented by the rules of a country. While internationalization is an activity based on people awareness, on a voluntary basis.

Point of similarity in the interchanged definition of globalization and internationalization is the cooperation between one or more countries in trade including in educational services. This brings about the phenomenon of General Agreement on Trade in Services (GATS). This agreement allows education services from any country to enter any country without exception. In this case, Bashir (The World Bank, 2007) states: "International trade in higher education services has grown rapidly in recent years in a variety of forms. The most common form of this trade is the movement of students to study in foreign universities, which has been supplemented by the delivery of foreign higher education programs and institutions to transition and developing countries".

Indonesia also takes part in the globalization of education by ratifying General Agreement on Trade in Services (GATS) in 1994. This agreement is the entryway of foreign universities to provide higher education services in Indonesia. This was followed up by the Minister of Trade Regulations 2005 on the requirements of foreign universities to run their services in Indonesia. The regulations are:

1) Only a foreign accredited university can conduct programmes of study; unaccredited foreign institutions are not allowed

2) Its presence is limited to five major cities (Medan, Jakarta, Bandung, Bogor and Yogyakarta)

3) It has to collaborate with a local university, invest in infrastructure, and involve local staff in its operation

4) It also has to comply with national standards and regulations, including a mutual recognition agreement (Nizam, 2006).

The ratification gave birth to some derived policies and rules as a more operational regulation. The Law of the Republic of Indonesia No. 20 of 2003 on National Education System, in article 65 regulates the organization of education by foreign country's institution in Indonesia. Government Regulation No. 103 of 2007 is the ratification of Regional Convention on the Recognition of Studies, Diplomas, and Degrees in Higher Education in Asia and the Pacific. The Minister of National Education Regulation No. 26 of 2007 regulates Higher Education Cooperation in Indonesia with Foreign Universities or Other Institutions. Another regulation on the Decree of Minister of National Education 223/1998 article 9 stating that foreign universities or institutions can cooperate in the form of management contract with universities in Indonesia that already exist.

Some foreign universities currently have begun expansion into Indonesia's market share in various forms, some of which are providing the service of education consultant, establishing branches in Indonesia, and working with universities in Indonesia, with a goal of getting excellent students of Indonesia.

With a population of higher-education-age reaching more than 25 million people, Indonesia is a very interesting market potential for foreign universities. The condition should be a concern of all parties concerned with higher education in Indonesia. Universities in Indonesia must continue to develop themselves, improve the quality and relevance, to be more competitive amid the expansion of foreign universities in Indonesia.

Indonesia currently has 82 State Universities and more than 2800 Private Universities and one Open University under the supervision of the Ministry of Research, Technology, and Higher Education. Meanwhile, there are 577 State Islamic Universities under the Ministry of Religious Affairs (53 State and 524 Private). These universities accommodate about 4.5 million students from about 25 million people aged 18-24 years, so the gross enrollment rate of higher education is about $17 \%$, while the population with education above senior high school is about $8 \%$. The growth of the universities is very rapid; the Gross Enrollment Rate in 1975 is only about 2\%, while in 2013 has reached 19.97\%. Central Bureau of Statistics (2017) describe in Table 1. 
Table 1. Gross Enrollment Rate of Higher Education

\begin{tabular}{lll}
\hline Component & $\mathbf{2 0 1 3}$ Male: Female & \\
\hline Age 19-24 years & $25,350,900$ & 0.95 \\
State Universities & $1,132,427$ & 0.87 \\
Private Universities & $2,745,881$ & 0.81 \\
Teachers' In-Service Training & 47,253 & 0.81 \\
Islamic Universities & 585,741 & 1.01 \\
Open Universities & 521,644 & 1.63 \\
The Number of Students & $5,062,574$ & 0.94 \\
Gross Enrollment Rate & $19.97 \%$ & 5.13 \\
\hline
\end{tabular}

The figures are still far below the achievements of Southeast Asian countries, especially compared with developed countries. The gross enrollment rate in Malaysia reached 32.5\%, Thailand $42.7 \%$, Philippines $28.1 \%$, even China has reached 20.3\%, while South Korea reached 91\%. According to Effendi (2005) the low enrollment rate of higher education and the quality of education which lag far behind the international quality standard make Indonesia as the target of the countries exporting education and training services. Both reasons are often the reasons for "inviting" foreign providers of education and training to come to Indonesia.

Although the gross enrollment rate of higher education in Indonesia is still relatively low, ironically, many university graduates are not getting jobs. Data from Central Bureau of Statistics in 2007 show the number of unemployed graduates reaching more than 400,000 people. This is an indicator showing that many universities in Indonesia have not been able to produce graduates with the quality that can meet the expectations and needs of employment. It is an alert on the necessary of quality improvement.

In response to these challenges and opportunities, since 2003, the Directorate General of Higher Education has developed a Higher Education Long Term Strategy (HELTS) 2003-2010. The keyword of the strategy is the placement of higher education as the key to strengthen the nation's competitiveness through the improvement of the quality of higher education to develop the students' potential optimally. The competitiveness of universities is encouraged through the independence in developing programs, mobilizing resources optimally, and utilizing them efficiently and effectively. Partnerships and cooperation between universities are encouraged to create fair and competitive synergies. A resource sharing is expected between the collaborating universities through such cooperation and partnership.

Without partnerships and cooperation of domestic and foreign universities, there will be a migration of students of one country to another. The migration occurs because there are 4 groups of players in the implementation of internationalization of higher education, namely:

1) The Major Players: The United States, the United Kingdom, and Australia;

2) The Middle Powers: Germany and France;

3) The Evolving Destinations: Japan, Canada, and New Zealand; and

4) The Emerging Contenders: Malaysia, Singapore, and China (Verbik and Lasanowski, 2007).

Ninnes and Hellsten (2005) stated that many countries are recruiting foreign students aggressively, such as Australia and New Zealand. The data cited by Jane and Izhar (2006) suggest that more than 1.6 million students have been going abroad to study, and more than 547,000 students study in the United States. The research results of Fiocco (2005) indicate that education is an export industry which contributes $\$ 5.6$ billion in revenue to the Australian economy.

Welch cited by Hong and Songan (2011) has reported that many Southeast Asian countries become the importers of transnational education from Australia and the United Kingdom. However, he further notes that in importing transnational education, the countries such as Malaysia, Thailand and Singapore sometimes also become exporters, through the provision of educational services for students from neighboring countries and establishing higher education institutions across the borders. The three countries also have a national goal to become a regional 
education hub. Malaysia exemplifies this best strategy, in which the government has actively supported and provided incentives for universities abroad to establish branch campuses, such as Nottingham University, Monash University, Swinburne University and Curtin University, and the Malaysian Open University. Whereas in Indonesia, the situation is quite different.

According to the report by Anna Papadopoulos (2020), Indonesia ranks 93 out of 132 countries with high living costs. This means that it is neither too expensive nor too cheap to stay for a study in Indonesia. This is no different from the cost of study, that according to the report by excelajah (2020), Indonesia is in the position which is neither cheap nor expensive. Unfortunately, this condition is not properly utilized by colleges or universities, resulting in not many foreign students are flocking to study in Indonesia.

Besides, Indonesia also has a high number of students studying abroad. To reduce the acceleration of the migration of Indonesian students abroad, in 2009, the Ministry of National Education budgeted billions of rupiahs to support the internationalization of 17 state universities in Indonesia. Asian markets tend to choose Europe and America. The adequacy of the quantity and quality aspects of lecturers and international accreditation also needs special attention.

Again, internationalization is part of the efforts to gain international recognition. Internationalization of universities in Indonesia should not be done individually but collectively and institutionally and facilitated by the ministry. Internationalization of Islamic universities in Indonesia is a matter of significance since Indonesia is a populous moslem country. The role of Islamic universities in implementing internationalization contribute to the internationalization of higher education in Indonesia which can improve the competitiveness of Indonesian universities in international academic forum.

There are more than 500 Islamic Universities spread throughout Indonesia under the supervision of the Ministry of Religious Affairs. The higher education institutions under the Ministry of Religious Affairs can be classified into four, namely: Islamic universities, institutes, academies, and private universities.

The Ministry of Religious Affairs has developed the internationalization capacity of state Islamic universities since 1950. They build cooperation with Canada, Netherlands, Egypt, Sudan, Australia, Germany, Saudi Arabia, and Algeria. At first, the cooperation is only in the form of sending lecturers of state Islamic universities to study abroad, then it is improved to the international cooperation.

Among the state Islamic universities having cooperation with foreign universities are State Islamic University of Yogyakarta and State Islamic University of Malang (Directorate of State Islamic University, 2005). According to the Ministry of Religious Affairs, State Islamic University of Yogyakarta has developed its capacity of institutional internationalization since 1994. It is done through the provisions of scholarships, joint research, visiting professor, and some trainings with foreign universities. The establishment of a new study program also realizes internationalization policy, namely, Interdisciplinary Islamic Studies at master programme which is more emphasized on social work. State Islamic University of Yogyakarta already has the certificate of quality management system of ISO 9001:2008, to attract foreign students to come.

Similarly, State Islamic University of Malang that has been developing internationalization capacity since it was inaugurated as Islamic University of Indonesia-Sudan has got recognition in the quality of management system with international standard of ISO 9001:2000.

Being outstanding as the leading universities in conducting internationalization among other Islamic state universities, it is interesting to portrait the implementation of internationalization in the State Islamic University of Yogyakarta and State Islamic University of Malang in some aspects.

This research aimed to determine strategic planning, research activities, and curriculum of internationalization policy in the State Islamic University of Yogyakarta and State Islamic University of Malang.

\section{Literature Review}

The implementation of higher education internationalization cannot be separated from its vision, program, and activities. Therefore, some researches on university internationalization policy discuss various aspect of the three. Research by Rosyidah, Matin, and Rosyidi (2020) talked about strategy of promoting internationalization which includes: First, the direction of universities to be recognized globally with a strong vision, international accreditation for their study programs, and a center for special studies. Second, universities publicize their programs, activities, excellence, and uniqueness through printed media or online, foreign institutions, and individuals. Third, universities initiate international collaboration with foreign universities and institutions by building good interpersonal communication, forming teams for international collaboration, initiating activities to build trust between individuals, 
and engaging in international events. Fourth, universities offer scholarships for foreign students to increase incoming students. From this research, it can be inferred that aspect of the vision must be directed to a strong effort to achieve internationalization. In the promotion strategy, promotion should not be limited to domestic sphere but also abroad. Besides, it is necessary to gain more foreign trust through international accreditation and collaboration.

Zakaria, etal. (2018), found that Malaysian students had a higher frequency of meta-discourse utilization than Pre-University Arab students in both components: interactive and interactional. This research also shows that there are significant differences in the frequency of interactional meta-discourse markers used in academic writing between Malaysian and Arab students. Clearly, Malaysian students use a variety of meta-discourse markers compared to Arab students, and have more meta-discourse markers in their essays than Arab pre-university students. It showed that foreign students need to get improvement on foreign language proficiency to ease and quicken their adaptation to a new different environment.

Strengthening the adaptation speed of foreign students in the destination country requires comprehensive efforts from universities. This is in line with the study conducted by Robati and Tonkaboni (2017) stating that some universities are preferred over others due to the tendency of the students and the university's instructors, to work and teach at these universities, which requires new study programs (especially the Ph.D.) that is offered. Other matters are the higher education quality ranking: Domestic higher education institutions have less intensive communication with foreign universities, lack of scholarships, less scientific communication with foreign countries, and lack of facilities that can be used by foreign students. There is another factor which makes foreign students want to enter higher education institutions abroad, that is the administration of adaptation program for foreign students in order to be able to immediately understand the environment, and to get used to the new language and culture. Comprehensive efforts explained in this research showed that universities must have new academic programs, achievement of higher education quality rankings, cooperation with foreign universities, strong scientific communication with foreign universities, and availability of scholarships.

The two studies mentioned before show that internationalization places more emphasis on the large number of foreign students who enter domestic universities. This step, according to the research by Teichler (2017) is more identical with internationalization and mobility. Students go to universities abroad. This mobility leads the students to academic and general skills, as well as international skills. However, in the future there will be a trend of internationalization without mobility that will play an increasing and stronger role, gradually. This is influenced by, one among those, international political conflicts.

This research seeks to obtain data related to the systematization of internationalization which is based on the planning carried out in the implementation of internationalization policies, as well as the support of the curriculum to the implementation of internationalization. In addition, these findings are planned on the mastery of international skills through curriculum support and research activities according to international needs.

\section{Research Methodology}

This research used qualitative approach to describe the implementation of internationalization policy in State Islamic University of Yogyakarta and State Islamic University of Malang. Research subject was the head of State Islamic University of Yogyakarta and State Islamic University of Malang along with the staffs. The data collection used interviews, observations, and documentation. The data validation used triangulation of source and method. The data analysis used an interactive model.

\section{Findings}

\subsection{Strategic Planning of Internationalization in State Islamic Universities}

Strategic planning is vital in institutional development. Based on this principle, policy and programs are made to achieve one goal. The strategic planning of the two universities can be described as follows: 
Table 2. The difference in strategic planning of internationalization

\begin{tabular}{|c|c|c|}
\hline Scope & $\begin{array}{l}\text { State Islamic University of } \\
\text { Yogyakarta }\end{array}$ & $\begin{array}{l}\text { State Islamic University of } \\
\text { Malang }\end{array}$ \\
\hline $\begin{array}{l}\text { The Statement of } \\
\text { Vision and Mission of } \\
\text { the University Level }\end{array}$ & $\begin{array}{l}\text { The statement of strategic } \\
\text { planning reflected in the vision } \\
\text { and mission of the State Islamic } \\
\text { University of Yogyakarta has not } \\
\text { explicitly stated the direction of } \\
\text { internationalization. }\end{array}$ & $\begin{array}{l}\text { The statement of strategic } \\
\text { planning reflected in the vision } \\
\text { and mission of the State Islamic } \\
\text { University of Malang has not } \\
\text { explicitly stated the direction of } \\
\text { internationalization. }\end{array}$ \\
\hline $\begin{array}{l}\text { The Statement of } \\
\text { Vision and Mission of } \\
\text { the Institutional Level } \\
\text { Managing } \\
\text { Internationalization }\end{array}$ & $\begin{array}{l}\text { The direction of statement of } \\
\text { strategic planning reflected in } \\
\text { vision and mission of institutional } \\
\text { level directly managing } \\
\text { internationalization has begun to } \\
\text { find direction. }\end{array}$ & $\begin{array}{l}\text { The direction of statement of } \\
\text { strategic planning reflected in } \\
\text { vision and mission of institutional } \\
\text { level directly managing } \\
\text { internationalization has begun to } \\
\text { find direction. }\end{array}$ \\
\hline $\begin{array}{l}\text { Strategic Planning of } \\
\text { University Level }\end{array}$ & $\begin{array}{l}\text { The direction of strategic } \\
\text { planning } \\
\text { internationalization has not been } \\
\text { clear }\end{array}$ & 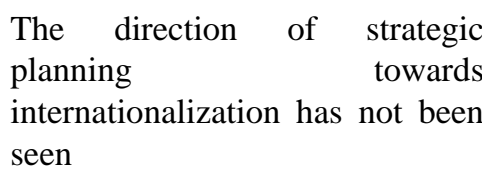 \\
\hline
\end{tabular}

From the statement of strategic planning reflected in the vision and mission of university level, the two institutions have not explicitly stated the direction of internationalization. It will be different when viewed from the institution directly managing internationalization whose direction has begun to be seen. The comparison shows the different seriousness in the implementation of internationalization policy. This is because State Islamic University of Yogyakarta as the oldest state Islamic university more often gets entrusted program to perform internationalization since the beginning. Whereas State Islamic University of Malang, initially a regional Faculty, must work fully to develop its institution internally and build the readiness in getting opportunities from the Ministry of Religious Affairs of Indonesia. The change of State Islamic Academy of Malang into Islamic University of Indonesia-Sudan of Malang is a reflection of readiness to synergize with the interest of the Ministry of Religious Affairs to develop the institution.

Strategic planning is central to institutional development, especially internationalization. This is because strategic plan is the initial foundation for the development of institution from the issues of financial planning, budgeting, human resources, academic programs, to realization.

University-level strategic planning should be in line with institutional strategic planning under it, so clarity is needed at the parent level to facilitate implementation into the programs, activities, and budgeting. This is in accordance with Steiss's (2003) statements stating that "A vision statement should present a guiding image of what success will look like, formulated in terms of an organization's anticipated contribution to the broader society. A vision statement is more encompassing than a mission statement in that it seeks to provide an image of success that will motivate people within the organization to work together".

Clear vision and mission of internationalization within an institution make it easier to make strategic choices. Consequently, the locality-seeking approach can be integrated with markets and services across the world. Here, the offer from Inkpen and Ramaswamy (2006) referred to as hybrid approach is needed. This approach seeks to capture the best elements of both sides with the integration of locality and global approach. The most important effort in this approach is in the framework of balancing locality pressures with the demand for cross-country integration.

4.2 The Curriculum Ensuring the Implementation of Internationalization Policy at State Islamic University of Yogyakarta and State Islamic University of Malang

The two universities have sought to develop an internationalization policy through Foreign Languages curriculum (Arabic and English) in the first semester. Foreign languages learning involves four language skills, namely; listening, speaking, reading, and writing. The understanding and mastery of the four languages skills is well intended to enable the learners to apply the languages properly. The development of foreign languages skills does not only occur in the classroom but also through the obligations of new students to be at the ma'had to joint shabahullughah language program. 
At the State Islamic University of Malang, foreign language skills is also supported by the establishment of foreign language environment at mosque, i.e., the use of foreign language in Friday sermon. In addition, International Class Program is established in several faculties of under-graduate program, and multicultural development is done through the subject of Religious Studies in the Faculty of Shari'ah.

At the State Islamic University of Yogyakarta, International Class is only held in master program. Foreign Languages curriculum (Arabic and English) is given in the early semester, and multicultural development is given through two subjects. The details on the curriculum support on the internationalization policy is shown in Table 4 .

Table 3. The Difference in Curriculum Support

\begin{tabular}{|c|c|c|}
\hline Scope & $\begin{array}{l}\text { State Islamic University of } \\
\text { Yogyakarta }\end{array}$ & State Islamic University of Malang \\
\hline $\begin{array}{l}\text { Foreign } \\
\text { Languages } \\
\text { Curriculum }\end{array}$ & $\begin{array}{l}\text { Start at the first semester, English } \\
\text { and Arabic }\end{array}$ & $\begin{array}{l}\text { Start at the first semester, English and } \\
\text { Arabic }\end{array}$ \\
\hline $\begin{array}{l}\text { International } \\
\text { Class Program }\end{array}$ & Only exists in master program & Exists in undergraduate program \\
\hline \multirow[t]{2}{*}{$\begin{array}{l}\text { Multicultural } \\
\text { Development }\end{array}$} & $\begin{array}{l}2 \text { subjects at University Level: } \\
\text { Religious Studies, and Islam and } \\
\text { Local Culture }\end{array}$ & $\begin{array}{l}1 \text { subject at University Level: } \\
\text { Religious Studies }\end{array}$ \\
\hline & $\begin{array}{l}\text { The faculty level is more } \\
\text { complete at the Faculty of } \\
\text { Ushuluddin, especially in } \\
\text { Department of Comparative } \\
\text { Religion }\end{array}$ & $\begin{array}{l}\text { The faculty level is more complete at } \\
\text { the Faculty of Shari'ah, especially in } \\
\text { the Department of Family Law (Al } \\
\text { Akhwal Asysyakhsiyyah). }\end{array}$ \\
\hline $\begin{array}{l}\text { Carrying capacity } \\
\text { of foreign } \\
\text { languages and } \\
\text { multicultural } \\
\text { development }\end{array}$ & $\begin{array}{l}\text { No Ma'had ' Ali inside the campus } \\
\text { for students }\end{array}$ & $\begin{array}{l}\text { Ma'had 'Ali in campus for students } \\
\text { (Indonesian and Foreign) in first } \\
\text { semester with the featured program of } \\
\text { shabahullughah }\end{array}$ \\
\hline $\begin{array}{l}\text { Carrying capacity } \\
\text { of foreign } \\
\text { languages and } \\
\text { multicultural } \\
\text { development out } \\
\text { of lectures }\end{array}$ & No other places but in lectures & $\begin{array}{l}\text { One campus mosque holds } \\
\text { foreign-language Friday sermon }\end{array}$ \\
\hline
\end{tabular}

The results above are consistent with the research conducted by Abdi O. Shuriye (2011) stating that:

If you have German students who are interested to learn Islam teach them in German language. This could be done, for instance by teaching Islamic subjects in diverse languages. If you have German students who are interested to learn Islam teach them in German language. Curr

ently the same students have to learn English or Arabic to learn Islam. Islamic universities should offer short courses on subjects in demand across the world. To promote internationalization exchange of academic staff and students is required. This exposes staff and students to other cultures and approaches; it should be done in a proportionate form by learning from other institutions and inviting others to learn from us.

In addition, the use of foreign languages should be accompanied by the courses of multicultural development, so that it can develop a generation that could be familiar with any differences in their vicinity. Foreign languages and multicultural skills development can prepare the generation that understands differences of culture and anything to ease cooperation with other parties. This is confirmed by the opinion of Hudzit that internationalization can be a means to prepare graduates for life and work in a global market of products, services, and ideas. Moreover, Zeleza (2012) stating that:

Economically, internationalization is justified for preparing students for careers in a globalized economy, enhancing national development and competitiveness, and as a means of generating extra institutional income. Politically, it is 
claimed, internationalization can promote understanding so essential for peace and security in the post-9/11 world and the development of global citizenship.

Nokkala (2006) also stated that we live in a global world where countries compete to become knowledge workers and the labor market has become global. Therefore, graduates require international expertise for the labor market. And to teach the skills and educate people with international-orientation, we need to internationalize our higher education and universities.

Similarly, Jackson and Huddart (2001) stated that "Global businesses are increasingly recruiting globally. Graduates who have international experience are highly employable because they have demonstrated that they have drive, resilience, and inter-cultural sensitivities as well as language skills.

The benefit of internationalization is delivered by Otten (2003): One of the main objectives of internationalisation or international education is the development of intercultural competence or of sensitivity.

Preparation of students and alumni who are ready to work in different cultures is not only to associate with foreign students but also through the curriculum with international perspective that develops multicultural skills. It is called internationalization at home, as the opinion of Eade and Peacock (2009):

Interest in 'internationalisation at home' is gathering momentum in UK higher education in the light of global competition and the need to prepare students for global employability and citizenship. Respect for others and intercultural learning are at the heart of this agenda, which is dependent on inclusive approaches to the delivery and development of formal and informal curricula, pedagogy, and student support functions.

Internationalization at home is developing an international environment in college. This formation is in the framework to make the use of foreign languages conducive and understand the cultural differences as presented by Executive Committee ESU (2003) that:

Creating an international environment is crucial in order to benefit from all aspects of internationalisation. Not everyone has the possibility to study abroad for a diverse number of reasons. In order to assure the international character of studies for everyone, as well as the general quality of teaching, learning and research, each university should pay careful attention to creating an international environment at their institution. Every student must have the chance to be part of internationalisation. To ensure that, there has to be free language classes provided at higher education institutions.

4.3 The Research Activities Ensuring the Implementation of Internationalization Policy at State Islamic University of Yogyakarta and State Islamic University of Malang

The striking difference between the two institutions lies in scientific publications. State Islamic University of Yogyakarta develops international journals that do not only use foreign language in the writing but also various authors and peer review. This is different from State Islamic University of Malang which more emphasizes on the development of scientific publications through the internet. The differences can be described as follow:

Table 4. The Difference of Research Activities

\begin{tabular}{|c|c|c|}
\hline Scope & $\begin{array}{l}\text { State Islamic University of } \\
\text { Yogyakarta }\end{array}$ & $\begin{array}{l}\text { State Islamic University of } \\
\text { Malang }\end{array}$ \\
\hline $\begin{array}{l}\text { Research } \\
\text { Publications and } \\
\text { Scientific Papers of } \\
\text { Lecturer }\end{array}$ & $\begin{array}{l}\text { State Islamic University of } \\
\text { Yogyakarta develops international } \\
\text { scientific journal }\end{array}$ & $\begin{array}{l}\text { Publications of on-line scientific } \\
\text { papers and essays use Indonesian } \\
\text { and English language. Foreign } \\
\text { citation index, especially } \\
\text { non-religious sciences }\end{array}$ \\
\hline Research Financing & $\begin{array}{l}\text { Framework for the development } \\
\text { of academic quality and } \\
\text { fundraising }\end{array}$ & $\begin{array}{l}\text { Framework for the development of } \\
\text { academic quality and fundraising }\end{array}$ \\
\hline Research Funding & $\begin{array}{l}\text { From foreign universities } \\
\text { foreign funding providers }\end{array}$ & $\begin{array}{l}\text { Still limited to funding from foreign } \\
\text { universities }\end{array}$ \\
\hline
\end{tabular}

The research activities and the publications is the "funnel" for the institution to be known in the country itself and abroad. Both institutions differ in their implementation. State Islamic University of Yogyakarta focuses on international printed journals of Al Jami'ah, while State Islamic University of Malang more uses on-line way for the publication of scientific works and international citations index. The similarity of both universities is in terms of 
research funding through foreign channels within the framework of academic quality and fundraising development. In terms of funding, State Islamic University of Yogyakarta is very proactive to get foreign fund for lecturer research, so that is not limited to domestic fund and foreign universities.

Such scientific publications make Islamic universities familiar to people outside their country institutionally and personally.

\section{Conclusions}

Strategic planning of internationalization at state Islamic universities at the university level is in line with the executor level, thus affecting the clarity of the strategy chosen. The two universities have been working to develop internationalization policy through the foreign languages curriculum (Arabic and English) in the first semester and multicultural skills with a difference on the subject or the faculty/department developing it. Foreign language development is carried out by developing foreign language environment both in the classroom and in ma'had with the shabahullughah program as well as through foreign-language use in Friday sermon. In addition, foreign language class, namely, International Class Program for undergraduate students at State Islamic University of Malang is also implemented. While master program using foreign languages as the language of instruction is implemented in the Department of Islamic Interdisciplinary Studies. In addition to foreign languages development, multicultural development is also established through the subject of Religious Studies in both state Islamic universities and at the department level in accordance with the scientific studies. The striking difference between the two institutions lies in scientific publications. State Islamic University of Yogyakarta develops internationally cited international scientific journals while State Islamic University of Malang focuses more on online publications and the improvement of lecturers' quality in scientific publications in international citations. Implication of this research is the description on systematized internationalization implemented at the State Islamic University of Yogyakarta and the State Islamic University of Malang can be a good reference for other State Islamic Universities in Indonesia.

\section{References}

Altbach, Philip G. (2004). Globalisation and the University: Myths and Realities in an Unequal World. Tertiary Education and Management, 10(1), 3-25. https://doi.org/10.1080/13583883.2004.9967114

Badan Pusat Statistik. (2017). Umlah Perguruan Tinggi, Mahasiswa, Dan Tenaga Edukatif (Negeri Dan Swasta) Di Bawah Kementrian Pendidikan Dan Kebudayaan Menurut Provinsi 2013/2014-2014/2015 (Jakarta, 2017)

Bentao, Yuan. (2011). Internationalization at Home. Chinese Education \& Society, 44(5), 84-96. https://doi.org/10.2753/CED1061-1932440507

Cantwell, Brendan, \& Alma Maldonado-Maldonado. (2009). Four Stories: Confronting Contemporary Ideas about Globalisation and Internationalisation in Higher Education. Globalisation, Societies and Education, 7(3), 289-306. https://doi.org/10.1080/14767720903166103

Direktorat Perguruan Tinggi Agama Islam. (2005). Profil Kerjasama Internasional Bidang Pendidikan Tinggi Agama (Jakarta: Departemen Agama, 2005)

Djokopranoto, Rchardus,\& Rchardus Eko Indrajit. (2004). Manajemen Perguruan Tinggi Moderen (Jakarta: PERBANAS)

Effendi, Sofian. (2005). Strategi Menghadapi Liberalisasi Pendidikan Tinggi, in Pendidikan Tinggi Di Era Pasar Bebas (Jakarta: UIN Jakarta, 2005), 1-12.

excelajah. (2020). The Cheapest vs The Most Expensive Countries to Study Abroad in The World. World $\begin{array}{llccr}\text { Scholarship } & \text { Forum } & \text { June } & 8, & 2020 .\end{array}$ https://worldscholarshipforum.com/cheapest-vs-expensive-study-abroad-locations-world/

Executive Committee. (2003). Policy Paper on Mobility and Internationalisation of Higher Education (Austria, 2003)

Fiocco, Maria. (2005). Glonacal Contexts: Internationalisation Policy in the Australian Higher Education Sector and the Development of Pathway Programs (Murdoch University, 2005)

Hénard, Fabrice, Leslie Diamond, \& Deborah Roseveare. (2012). Approaches to Internationalisation and Their Implications for Strategic Management and Institutional Practice (Organisation for Economic Co-operation and Development, 2012) www.oecd.org/edu/imhe

Hong, Kian-Sam, \& Peter Songan. (2011). ICT in the Changing Landscape of Higher Education in Southeast Asia. Journal of Educational Technology, 27(8), 1276-90. https://doi.org/10.14742/ajet.893 
Ika. (2009). Internasionalisasi: Jalan Untuk Peroleh Reputasi Dan Capai Tujuan Perguruan Tinggi. Universitas Gadjah Mada, 2009 https://ugm.ac.id/id/berita/630-internasionalisasi-jalan-untuk-peroleh-reputasi-dan-capai-tujuan-perguruan-tingg i [accessed 21 January 2019]

Inkpen, Andrew, \& Kannan Ramaswamy. (2006). Global Strategy: Creating and Sustaining Advantage across Borders (New York: Oxford University Press, 2006) https://doi.org/10.1093/acprof:oso/9780195167207.001.0001

Jackson, Elizabeth, \& Tina Huddart. (2001). 'Curriculum Design Based on Home Students' Interpretations of Internationalisation'. ARECLS, 7(2001), 80-112.

Jane, Hemsley-Brown, \& Oplatka Izhar. (2006). Universities in a Competitive Global Marketplace: A Systematic Review of the Literature on Higher Education Marketing. International Journal of Public Sector Management, 19(4), 316-38. https://doi.org/10.1108/09513550610669176

Jiang, Nan, \& Victoria Carpenter. (2013). A Case Study of Issues of Strategy Implementation in Internationalization of Higher Education. International Journal of Educational Management, 27(1), 4-18. https://doi.org/10.1108/09513541311289792

Jiang, Xiaoping. (2007). Towards the Internationalisation of Higher Education in the New Zealand Context. Philosophy of Education Society of Australasia, 1-14.

Knight, Jane. (1997). Internationalisation of Higher Education: A Conceptual Framework. Internationalisation of Higher Education in Asia Pacific Countries (Amsterdam, 1997)

- (2013). The Changing Landscape of Higher Education Internationalisation - for Better or Worse? Perspectives: Policy and Practice in Higher Education, 17(3), 84-90. https://doi.org/10.1080/13603108.2012.753957

Kushnarenko, Valentyna. (2010). International Collaboration in Higher Education: The Canadian-Ukrainian Curriculum Development Partnership (University of Toronto, 2010)

Levin, John S. (1999). Missions and Structures: Bringing Clarity to Perceptions about Globalization and Higher Education in Canada. Higher Education, 37(4), 377-99. https://doi.org/10.1023/A:1003635731222

Macgregor, Karen. (2008). Internationalisation: A Research Agenda. University World News, 2008 https://www.universityworldnews.com/post.php?story=20081017101149606 [accessed 9 January 2019]

Marginson, Simon, \& Marijk Van Der Wende. (2007). Globalisation and Higher Education OECD Working Paper. Education, 8, 2007. https://doi.org/10.1787/173831738240

Moorthy, Krishna. Johanthan, S., Hung, CC., Han, KC., Zheng, NZ., Cheng, WY., \& Yuan, WH. (2019). Factors Affecting Students Choice of Higher Education Institution: A Malaysian Perspective. World Journal of Vocational Education and Training, June 2019, 1(2), 59-74. DOI: 10.18488/journal.119.2019.12.59.74

Ninnes, Peter, \& Meeri Hellsten. (2005). Internationalizing Higher Education: Critical Explorations of Pedagogy and Policy, 1st edn (Dordrecht: Springer, 2005) https://doi.org/10.1007/1-4020-3784-8

Nizam. (2006). The Need For Higher Education Reforms. Higher Education in South-East Asia (Bangkok: UNESCO)

Nokkala, Terhi. (2006). Knowledge Society Discourse in Internationalisation of Higher Education Case Study in Governmentality. Revista Española de Educación Comparada, 12 (2006), 171-201.

Otten, Matthias. (2003). Intercultural Learning and Diversity in Higher Education. Journal of Studies in International Education, 7.1(2003), 12-26. https://doi.org/10.1177/1028315302250177

Papadopoulos, Anna (2020). Most Expensive Countries In The World To Live In, 2020. Stats Gate, February 3, 2020. https://ceoworld.biz/2020/02/03/most-expensive-countries-in-the-world-to-live-in-2020/

Peacock, Nicola, \& Neil Harrison. (2009). It's so Much Easier to Go with What's Easy": BMindfulness" and the Discourse between Home and International Students in the United Kingdom. Journal of Studies in International Education, 13(2). https://doi.org/10.1177/1028315308319508

Robati, Fatemeh-Al-Sadat \& Tonkaboni. F. (2017). Hidden Experiences of Doctoral Students In Research Courses. International Journal of Education and Practice 2017, 5(4), 61-68. https://doi.org/10.18488/journal.61.2017.54.61.68. 
Rosyidah, Naeli, Matin, \& Rosyidi, U. (2020). Internationalization in Higher Education: University's Effective Promotion Strategies in Building International Trust. European Journal of Educational Research, 9(1), (January 2020), 351-361. https://doi.org/10.12973/eu-jer.9.1.351

Seventh, David L. Goetsch Stanley Davis. (2014). Quality Management for Organizational Excellence:Introduction to Total Quality, Case Studies in Work, Employment and Human Resource Management, 7th edn (Pearson Education Limited, 2014) https://doi.org/10.4337/9781788975599.00039

Shuriye, Abdi O. (2011). Internationalization of Islamic Higher Learning Institutions in the Muslim World. Journal of Emerging Trends in Educational Research and Policy Studies (JETERAPS), 2(2011).

Singh, Mithilesh Kumar. (2016). Impact of Globalization on Indian Higher Education. Procademia, 2016 https://www.procademia.com/uploads/knowledge_library/8e440588c54e95a1dfb075280f2afaa55a07ad71.pdf [accessed 20 January 2020]

Steiss, Alan W. (2003). Strategic Management for Public and Nonprofit Organizations, 1st edn (Routledge, 2003)

Teichler, Ulrich. (2017). Internationalisation Trends In Higher Education And The Changing Role Of International Student Mobility Presses Universitaires de France. Journal of international Mobility, 2017/1 № 5 | pages 177 à 216 https://www.cairn.info/revue-journal-of-international-mobility-2017-1-page-177.htm https://doi.org/10.3917/jim.005.0179

The World Bank. (2007). Trends in International Trade in Higher Education: Implications and Options for Developing Countries (Washington, 2007)

Verbik, Line, \& Veronica Lasanowski. (2007). International Student Mobility: Patterns and Trends and Former Deputy Director, The Observatory on Borderless Higher Education (London, 2007), XLIV

Whitaker, Aliana M. (2004). The Internationalization of Higher Education: A Us Perspective (Virginia Polytechnic Institute and State University, 2004)

Zakaria, Muhamad Khairul, Malik, FA., Ab. Rashid, R., Pilus, Z., \& Zakaria, NS. (2018). Metadiscourse in the Academic Writing of Local and International Students at a University in Malaysia. International Journal of Education and Practice, April 2018, 6(4), 227-238. https://doi.org/10.18488/journal.61.2018.64.227.238

Zeleza, Paul Tiyambe. (2012). Internationalisation in Higher Education: Opportunities and Challenges for the Knowledge Project in the Global South. Internationalisation of Higher Education: Perspectives from the South, 2.2(2012), 6-18.

\section{Copyrights}

Copyright for this article is retained by the author(s), with first publication rights granted to the journal.

This is an open-access article distributed under the terms and conditions of the Creative Commons Attribution license (http://creativecommons.org/licenses/by/4.0/). 